\title{
Pengaruh Model Pembelajaran Problem Based Learning Berbasis Eksperimen Sederhana dalam Pengenalan Sains Anak Usia Dini
}

\author{
Christiani Endah Poerwati ${ }^{\circledR}$, I Made Elia Cahaya ${ }^{1}$, Ni Made Ayu Suryaningsih ${ }^{1}$ \\ Pendidikan Guru Pendidikan Anak Usia Dini, Universitas Dhyana Pura, Bali, Indonesia(1) \\ DOI: $\underline{10.31004 / \text { obsesi.v6i3.1233 }}$
}

\begin{abstract}
Abstrak
Sains penting dikenalkan pada anak usia dini dengan konsep sederhana melalui kegiatan eksperimen sederhana guna melatih kemampuan memecahkan masalah. Penelitian ini bertujuan untuk mengetahui pengaruh penerapan model pembelajaran problem based learning berbasis eksperimen sederhana terhadap kemampuan pengenalan sains anak usia dini. Jenis penelitian ini adalah quasi eksperimen, dengan rancangan posttest only control group design. Populasi penelitian adalah anak usia dini di Kecamatan Kuta Utara. Penentuan kelas kontrol dan kelas eksperimen digunakan sistem random. Pengumpulan data dilakukan dengan menggunakan lembar observasi. Teknik analisa data penelitian menggunakan analisis varians (anava) satu jalur. Hasil penelitian menunjukkan bahwa terdapat perbedaan kemampuan pengenalan sains pada anak yang mengikuti model pembelajaran problem based learning berbasis eksperimen sederhana dengan anak yang mengikuti pembelajaran Konvensional.. Kegiatan eksperimen sederhana mampu menolong anak dalam memecahkan masalah sains dengan tahapan kerja yang jelas. Melalui hasil penelitian ini dapat diperoleh suatu desain pembelajaran yang efektif untuk meningkatkan kemampuan pengenalan sains pada anak usia dini.
\end{abstract}

Kata Kunci: model pembelajaran problem based learning; eksperimen sederhana; pengenalan sains

\begin{abstract}
It is important to introduce science to early childhood with simple concepts through simple experimental activities to practice problem-solving skills. This study aims to determine the effect of the application of a simple experiment-based problem-based learning model on the ability to recognize science in early childhood. This type of research is a quasi-experimental, with a posttest only control group design. The research population is early childhood in Kuta Utara District. Determination of the control class and the experimental class used a random system. Data collection is done by using observation sheets. The research data analysis technique used one-way analysis of variance (ANAVA). The results showed that there were differences in the ability to recognize science in children who followed the simple experimentbased problem-based learning model with children who took conventional learning. Simple experimental activities were able to help children in solving science problems with clear stages of work. Through the results of this study, an effective learning design can be obtained to improve the ability to recognize science in early childhood.
\end{abstract}

Keywords: problem based learning model; simple experiment; introduce science

Copyright (c) 2021 Christiani Endah Poerwati, et al.

$\triangle$ Corresponding author :

Email Address : christianiendah@undhirabali.ac.id ( Bali, Indonesia )

Received 28 March 2021, Accepted 5 July 2021, Published 25 September 2021 


\section{PENDAHULUAN}

Salah satu capaian perkembangan yang penting adalah perkembangan kognitif. Perkembangan kognitif anak yang baik diperlukan untuk mempelajari dan mengeksplorasi lingkungan, memecahkan masalah, mempelajari sebab akibat, serta kemampuan berpikir lainnya, karena kemampuan kognitif merupakan kemampuan memroses informasi dari lingkungannya melalui panca indera (Hunt dalam (Sit, 2017)). Mempelajari sains dapat dikenalkan pada anak usia dini sebagai upaya meningkatkan kemampuan berpikir logis anak. Pengenalan sains pada anak sebaiknya dikemas dalam pembelajaran yang menarik dan menyenangkan, dengan menggunakan metode yang sesuai dengan usia, tingkat perkembangan anak dan melibatkan seluruh panca inderanya.

Menurut Carol Seefeldt dan Barbara A. Wasik (Seefeldt \& Wasik, 2008) bahwa anakanak prasekolah dan TK tidak selayaknya dijejali dengan segudang konsep. Mengingat banyak dan luasnya pengetahuan ilmiah, maka sains dapat diajarkan sedari dini walau hanya sebatas pengenalan. Namun konsep-konsep embrio ini akan membentuk landasan untuk belajar sains di masa mendatang. Sedangkan (Morrison, 2012) menyatakan bahwa sains penting diajarkan pada anak usia dini karena sains merupakan sarana anak bertanya tentang alam sekitarnya, sebagai literasi sains, anak dapat belajar bahasa lisan dan tertulis ketika mengeksplorasi sains, anak dapat belajar mengapresiasi keragaman hayati dan keterkaitannya, sians mengajar anak menghormati dan peduli dengan alam semesta, anak belajar menjadi ilmuwan, dan belajar menyukai sains sedari dini. Pengenalan sains pada anak usia dini dapat dilaksanakan melalui berbagai aktivitas bermain, kegiatan, dan metode yang memungkinkan anak mendapat kesempatan untuk mengeksplorasi lingkungan dan alam sekitarnya.

Pengenalan sains sebagai bagian dari pengembangan kemampuan kognitif dapat diberikan pada anak, namun pada prakteknya di PAUD pengenalan sains baru sebatas pada teori dan hafalan. Hasil penelitian (Husin \& Yaswinda, 2021) menyatakan bahwa pembelajaran sains pada anak usia dini hampir $47 \%$ guru PAUD menyatakan jarang melakukan. Selain itu pembelajaran sains masih sering dijumpai disampaikan guru melalui metode yang kurang inovatif, sehingga sains menjadi pembelajaran yang kurang menarik dan menyenangkan. Guru perlu memilih dan mencoba metode pembelajaran yang interaktif dan inovatif sehingga pembelajaran sains dapat disampaikan sebagai sains proses bukan hanya sains produk, sebagaimana dilakukan dalam penelitian (Marliza \& Eliza, 2019).

Pengenalan sains pada anak usia dini akan dapat lebih efektif dengan menerapkan metode pembelajaran yang tepat, yang memungkinkan anak bukan hanya mempelajari berbagai konsep sains tetapi menemukan dan mengalami pengetahuan itu sendiri selama pembelajaran. Model pembelajaran Problem Based Learning merupakan salah satu model pembelajaran yang menarik dan menantang kemampuan berpikir anak untuk mempelajari sains. Melalui proses PBL, anak datang dengan konsep awal untuk menjelaskan fenomena yang disajikan dalam bentuk masalah. Studi sebelumnya telah menunjukkan bahwa terdapat pengaruh positif terhadap motivasi, minat dan belajar apabila anak memiliki pilihan untuk menentukan apa yang ingin mereka pelajari (O'Grady, Glen, Yew, Elaine H.J., P.L, Karen. Schmidt, 2012). Model pembelajaran ini memungkinkan diterapkan pada anak usia dini, meningingat karakteristik anak yang mempunyai sifat ingin tahu yang besar, suka mengulang, suka menyelidik, suka tantangan dan senang mempelajari banyak hal, termasuk sains (Rachmawati \& Kurniati, 2011). Model pembelajaran Problem Based Learning dapat diterapkan pada anak usia dini untuk mempelajari sains tentunya dengan membuat desain pembelajaran yang sederhana dan sesuai dengan tingkat perkembangan anak.

Model pembelajaran Problem Based Learning menyediakan berbagai pengalaman belajar bagi anak dengan melatih memecahkan masalah melalui berbagai teknik dan media yang mendukung. Selain menggunakan metode proyek, Model pembelajaran Problem Based Learning dapat diterapkan pula dengan menggunakan metode eksperimen. Metode eksperimen sangat efektif diterapkan guna membantu anak memecahkan masalah dengan 
bantuan alat dan bahan serta langkah-langkah yang terstruktur. Namun perlu diperhatikan bahwa pengertian eksperimen untuk anak usia dini bukanlah suatu proses dan cara yang rumit yang agar dapat memahami konsep sains, melainkan harus ditekankan adalah bagaimana anak dapat menemukan solusi terhadap permasalahan yang ada dan anak dapat menemukan sesuatu yang bermanfaat dari kegiatan tersebut (Rachmawati \& Kurniati, 2011).

Pengenalan sains berbasis eksperimen akan menolong anak memecahkan masalah melalui pengalaman langsung dengan cara menyelidiki, mencoba dan membuktikan suatu konsep sains. Melalui model pembelajaran ini diharapkan anak dapat mempelajari sains dengan cara yang berbeda, menantang daya pikirnya dengan pengalaman belajar langsung dan menemukan sendiri pengetahuannya melalui pemecahan masalah. Pembelajaran yang mendukung anak untuk terlibat langsung dalam praktik ilmiah akan melatih keterampilan berpikir kritis anak untuk menjadi pembelajar ilmu seumur hidup (Crawford \& Capps, 2018). Tujuan model pembelajaran Problem Based Learning umumnya menantang dan mengasah kemampuan berpikir kritis, kemandirian belajar, keterampilan menggali informasi, pembelajaran kolaboratif dan tim, reflektif dan evaluatif (Tan, 2003). Sebagaimana telah dilakukan penelitian oleh (Wulandari \& Suparno, 2020) hasil penelitian menunjukkan bahwa terdapat pengaruh yang signifikan pada kemampuan kerjasama, penelitian (Muharromi \& Sa'ud, 2015) menunjukkan bahwa penerapan pembelajaran problem based learning berpengaruh terhadap kreativitas dan kemampuan berbicara, serta penelitian (Ulfa, 2020), problem based learning bahkan dapat diterapkan pada sekolah inklusi untuk meningkatkan sikap mandiri anak. Berdasarkan hal tersebut di atas penelitian ini dilaksanakan untuk mengetahui bagaimana pengaruh Model Problem Based Learning berbasis eksperimen terhadap pengenalan sains pada anak usia dini.

\section{METODOLOGI}

Penelitian ini merupakan penelitian eksperimen semu (quasi eksperiment). Model pembelajaran Problem Based Learning berbasis eksperimen sederhana diterapkan pada kelompok eksperimen, sedangkan kelompok kontrol menggunakan pembelajaran konvensional. Hasil pembelajaran kelompok eksperimen dibandingkan dengan kelompok kontrol. Karena penelitian dilakukan di lembaga PAUD maka tidak memungkinkan mengontrol semua variabel secara ketat (full randomize). Rancangan penelitian dapat dilihat pada gambar 1.

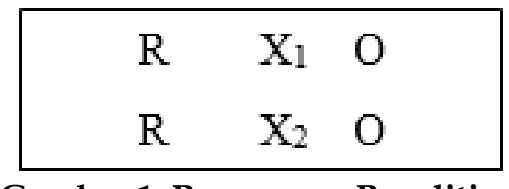

Gambar 1 Rancangan Penelitian

Sumber : (Sugiyono, 2017)

Keterangan pada gambar 1, X1 merupakan Pembelajaran Problem Based Learning, X2 adalah Pembelajaran dengan Model pembelajaran konvensional, dan O adalah Pengamatan Akhir berupa observasi pengenalan sains anak.

Populasi penelitian ini adalah seluruh anak di kelompok B, PAUD Pelita Kasih Dalung dengan jumlah 34 anak yang ada dalam 2 kelas. Penentuan sampel dilakukan dengan metode group random sampling, diperoleh kelas B1 dengan jumlah 17 anak sebagai kelas eksperimen dan kelas B2 sebagai kelas kontrol dengan jumlah 17 anak. Variabel bebas dalam penelitian ini adalah model pembelajaran Problem Based Learning dan konvensional sedangkan variabel terikatnya adalah pengenalan sains pada anak usia dini. Hubungan antar variabel pada penelitian ini ditunjukkan dalam Gambar 2.

Pada penelitian ini pengumpulan data dilakukan dengan metode observasi menggunakan lembar observasi kemampuan pengenalan sains pada anak usia dini baik kelas eksperimen maupun kelas kontrol. Penjelasan proses pembelajaran dilakukan secara Daring 

DOI: $10.31004 /$ obsesi.v6i3.1233

melalui media Zoom Clouds Meeting bekerja sama dengan orang tua anak, karena dilaksanakan pada masa pandemi Covid-19. Melalui diskusi dijelaskan langkah-langkah pengenalan sains model PBL berbasis eksperimen sederhana. Pembagian alat, bahan, lembar kerja anak dan video tutorial eksperimen sains sebagai sarana pembelajaran sains. Instrumen yang digunakan dalam penelitian berupa lembar observasi kemampuan pengenalan sains anak usia dini dengan penskoran menggunakan skala Likert, dengan degradasi mulai dari: sangat kurang, kurang, cukup, baik, dan sangat baik. Indikator instrumen lembar observasi mengacu pada Permendikbud No. 146 tahun 2014 (Permendikbud No 146, 2014. Kurikulum 13 Pendidikan Anak Usia Dini, 2014). Tabel 1 adalah kisi-kisi instrumrn penelitian.

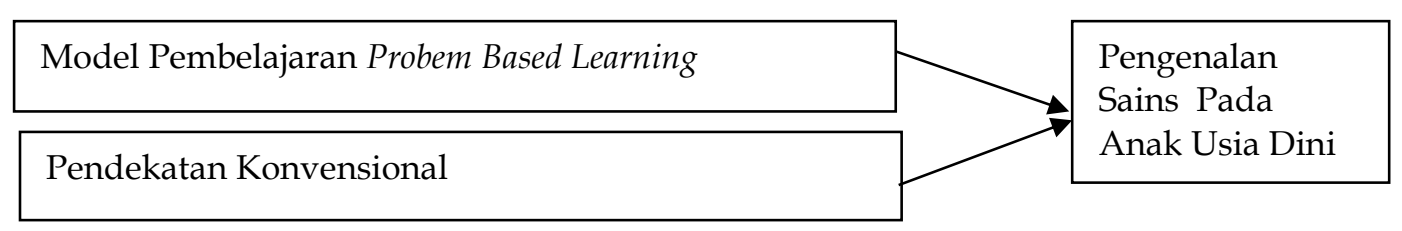

\section{Gambar 2. Hubungan antara Variabel-Variabel Penelitian}

Uji hipotesis dilakukan untuk mengetahui perbedaan yang signifikan antara kemampuan pengenalan sains anak dengan menerapkan model pembelajaran Problem Based Learning dibandingkan dengan pembelajaran konvensional pada anak usia dini. Teknik analisis data yang digunakan dari hasil penelitian adalah analisis varians (anava) satu jalur yang melibatkan satu variabel bebas dan satu variabel terikat (Sugiyono, 2017). Uji hipotesis penelitian dilakukan setelah data yang diolah telah memenuhi asumsi prasyarat analisis, yaitu homogen dan terdistribusi normal.

Uji instrumen dilakukan sebagai prasyarat sebelum pelaksanaan penelitian yang bertujuan untuk memberikan hasil ukur yang tepat dan akurat untuk menghasilkan data yang relevan. Instrumen penelitian yang telah dibuat diujikan pada 17 anak. Uji instrumen terdiri dari uji validitas dan realibitas.

Tabel 1. Kisi-Kisi Penelitian

\begin{tabular}{|c|c|c|c|}
\hline No & $\begin{array}{l}\text { Aspek/Dimensi } \\
\text { (Capaian } \\
\text { Perkembangan } \\
\text { Kognitif) } \\
\end{array}$ & Indikator/Butir & Kegiatan \\
\hline 1. & $\begin{array}{l}\text { Belajar dan } \\
\text { Pemecahan Masalah }\end{array}$ & $\begin{array}{l}\text { Anak mampu menunjukkan aktivitas } \\
\text { yang bersifat eksploratif dan } \\
\text { menyelidik } \\
\text { Anak mampu menerapkan } \\
\text { pengetahuan atau pengalaman dalam } \\
\text { konteks sehari-hari } \\
\text { Anak mampu menunjukkan sikap } \\
\text { kreatif dalam menyelesaikan masalah } \\
\text { dengan cara berbeda } \\
\text { Anak mampu mengenal sebab-akibat } \\
\text { tentang lingkungannya }\end{array}$ & $\begin{array}{l}\text { Eksperimen sederhana : } \\
\text { 1. Tenggelam - } \\
\text { terapung } \\
\text { 2. Berat udara } \\
\text { 3. Warna } \\
\text { 4. Mengembangkan } \\
\text { balon tanpa ditiup }\end{array}$ \\
\hline 2. & Berpikir logis & $\begin{array}{l}\text { Anak mampu mengikuti langkah- } \\
\text { langkah kegiatan eksperimen } \\
\text { Anak mampu mengungkapkan } \\
\text { pengetahuan/konsep sains dari hasil } \\
\text { eksperimen }\end{array}$ & \\
\hline
\end{tabular}

Uji Validitas 
Setiap butir indikator dari instumen penelitian diuji validitasnya dengan hasil seperti pada Tabel 2.

Tabel 2 Nilai Corrected Item-Total Correlation dan Nilai R Tabel

\begin{tabular}{cccc}
\hline Butir & $\begin{array}{c}\text { Corrected Item-Total } \\
\text { Correlation }\end{array}$ & R Tabel & Kesimpulan \\
\hline 1 & 0,962 & 0.482 & Valid \\
2 & 0,931 & 0.482 & Valid \\
3 & 0,662 & 0.482 & Valid \\
4 & 0,829 & 0.482 & Valid \\
5 & 0,904 & 0.482 & Valid \\
6 & 0,912 & 0.482 & Valid \\
\hline
\end{tabular}

\section{Uji Reliabilitas}

Indikator penelitian dihitung pula reabilitas setiap butirnya. Hasil pengukuran Uji Reabilitas ditampilkan pada Tabel 3.

Tabel 3 Nilai Cronbach's Alpha if Item Deleted Nilai R Tabel

\begin{tabular}{cccc}
\hline Butir & $\begin{array}{c}\text { Cronbach's Alpha if } \\
\text { Item Deleted }\end{array}$ & R Tabel & Kesimpulan \\
\hline 1 & 0,934 & 0.482 & Reliabel \\
2 & 0,940 & 0.482 & Reliabel \\
3 & 0,966 & 0.482 & Reliabel \\
4 & 0,950 & 0.482 & Reliabel \\
5 & 0,941 & 0.482 & Reliabel \\
6 & 0,940 & 0.482 & Reliabel \\
\hline
\end{tabular}

\section{HASIL DAN PEMBAHASAN}

Uji hipotesis dilakukan dengan metode statistika dengan formula Anova satu jalur, setelah hasil post test kemampuan pengenalan sains anak usia dini memenuhi uji prasyarat. Uji prasyarat yang dilakukan adalah uji normalitas dan uji homogenitas varians. Uji normalitas dilakukan untuk mengetahui apakah sebaran frekuensi data setiap variabel berdistribusi normal atau tidak. Uji normalitas pada penelitian ini menggunakan bantuan program SPSS 21.0 for windows dengan menggunakan lajur Kolmogorov-Smirnov dan Shapiro-Wilk. Kriteria yang dipakai adalah jika nilai signifikansi $>0,05$ maka data berdistribusi normal, sedangkan jika nilai signifikansi $<0,05$ menunjukkan data tidak berdistribusi normal. Di bawah ini disajikan tabel 4 hasil uji normalitas data penelitian.

Tabel 4. Rekapitulasi Hasil Uji Normalitas Data

\begin{tabular}{lcccccc}
\hline & \multicolumn{2}{c}{ Kolmogorov-Smirnova } & \multicolumn{3}{c}{ Shapiro-Wilk } \\
& Statistic & df & Sig. & Statistic & df & Sig. \\
\hline Konvensional & .176 & 17 & .171 & .924 & 17 & .176 \\
PBL & .099 & 17 & $.200^{*}$ & .974 & 17 & .890 \\
\hline
\end{tabular}

Tabel 4 di atas menunjukkan hasil uji normalitas pada kelas kontrol maupun eksperimen bahwa data tersebar normal pada semua unit analisis,. Nilai signifikansi pada uji statistic Kolmogorov-Smirnov maupun Shapiro-Wilk, menunjukkan nilai signifikansi lebih besar dari 0,05. Maka dapat dikatakan bahwa skor pengenalan sains pada anak usia dini pada kelas kontrol maupun kelas eksperimen berdistribusi normal.

Uji homogenitas dilakukan dengan uji Levene's Test of Equality of Error Variances (Levene's Test) yang dianalisis dengan menggunakan program SPSS 21 for windows. Data dikatakan memiliki varian yang sama jika angka signifikansinya lebih besar dari 0,05. Tabel 4 
Pengaruh Model Pembelajaran Problem Based Learning Berbasis Eksperimen Sederhana dalam Pengenalan Sains DOI: $10.31004 /$ obsesi.v6i3.1233

berikut ini merupakan hasil uji homogenitas varian data.

Tabel 5. Hasil Uji Homogenitas Data

Pengenalan Sains

\begin{tabular}{cccc}
\hline Levene Statistic & df1 & df2 & Sig. \\
\hline $1.283^{\mathrm{a}}$ & 10 & 22 & .298 \\
\hline
\end{tabular}

Data pada tabel 5, menunjukkan hasil angka signifikansi sebesar 0,298 lebih besar dari 0,05 . Artinya bahwa data pengenalan sains pada anak usia dini memiliki sebaran data yang homogen. Berdasarkan uji prasyarat, menunjukkan data yang diperoleh berdistribusi normal, dan varian data homogen. Pada tahap berikutnya dilakukan pengujian hipotesis menggunakan Analisis Univariat (ANAVA). Data hasil analisis ditunjukkan pada Tabel 6.

Tabel 6 Hasil Analisis ANAVA Satu Jalur

Pengenalan Sains

\begin{tabular}{lrrrrr}
\hline & Sum of Squares & df & Mean Square & F & Sig. \\
\hline Between Groups & 1.583 & 11 & .144 & .458 & .910 \\
Within Groups & 6.917 & 22 & .314 & & \\
Total & 8.500 & 33 & & & \\
\hline
\end{tabular}

Berdasarkan tabel 6 diperoleh taraf signifikansi 0,091 $(\mathrm{p}<0,05)$. Maka dapat disimpulkan bahwa hipotesis alternatif yang menyatakan bahwa"terdapat perbedaan hasil pengenalan sains pada anak usia dini yang belajar melalui model pembelajaran Problem Based Learning berbasis eksperimen sederhana dengan anak yang belajar melalui model pembelajaran konvensional" diterima. Maka dapat disimpulkan bahwa penerapan model pembelajaran Problem Based Learning berbasis eksperimen sederhana lebih efektif dalam meningkatkan pengenalan sains pada anak usia dini dibandingkan dengan metode konvensional.

Tabel 7 berikut menyajikan perbandingan rerata skor hasil observasi pengenalan sains pada anak usia dini menggunakan model pembelajaran Problem Based Learning dan metode konvensional.

Tabel 7 Perbandingan Rerata Skor Pengenalan Sains Anak Usia Dini

\begin{tabular}{cc}
\hline Kelas Eksperimen & Kelas Kontrol \\
\hline $\bar{X}=17$ & $N=17$ \\
$\bar{X}=20,06$ & $\bar{X}=18,41$ \\
\hline
\end{tabular}

Secara empiris berdasarkan hasil analisis deskriptif pengenalan sains anak usia dini menunjukkan bahwa pada kelas anak yang belajar dengan model pembelajaran Problem Based Learning berada pada kualifikasi berkembang sangat baik dan kelas yang belajar dengan pembelajaran konvensional berada pada kategori yang berkembang sesuai harapan. Skor rata-rata pada tabel 6, anak kelompok eksperimen (pembelajaran Problem Based Learning) memperoleh rata-rata 20,06 dan anak kelompok kontrol (Metode Konvensional) memperoleh rata-rata 18,41 .

Model pembelajaran PBL mampu meningkatkan dan mengembangkan kemampuan anak untuk terlibat aktif dalam pembelajaran dengan mengkonstruksi pengetahuan melalui penemuan mereka dengan bantuan praktik eksperimen sederhana, mencoba dengan cara berbeda, menghubungkan dan menerapkan berbagai konsep sains dalam kehidupan seharihari. Hal ini juga ditunjukkan melalui penelitian (Almulla, 2020) dengan mengidentifikasi lima aspek utama dari pendekatan PBL yaitu pembelajaran kolaboratif, pembelajaran antar disiplin ilmu, pembelajaran berulang, dan pembelajaran otentik, yang seluruhnya dapat menghasilkan keterlibatan siswa. 
Model pembelajaran Problem Based Learning merupakan model pembelajaran yang mempunyai tujuan mengasah kemampuan dan cara berpikir analitis, kreatif serta kritis berbasis masalah. Model pembelajaran ini sejatinya tepat diterapkan untuk kemampuan berpikir tingkat tinggi pada tingkat usia tinggi (Siagian \& Sinaga, 2019) namun pada usia dini model pembelajaran ini dapat pula diterapkan dengan masalah, tahap-tahap, serta instruksi yang sederhana. Selain itu model pembelajaran Problem Based Learning dapat pula dikembangkan dengan metode pendukung lainnya seperti metode proyek, eksperimen (Fidiyani et al., 2019), (Juniarti, 2017), atau model marquee sebagaimana diterapkan oleh Diastuti dan Sulto (Diastuti \& Sulton, 2021) untuk meningkatkan kemampuan literasi.

Pembelajaran dengan model Problem Based Learning melatih keterampilan berpikir kritis dan kemandirin anak untuk memecahkan masalah sesuai dengan tingkat usianya (Widiyarti, Wiwi \& Soetisna, 2021), dengan memberi rangsangan kegiatan eksperimen yang menantang rasa ingin tahu anak tanpa dibebani dengan pembelajaran instruksional yang membosankan. Hal ini juga dinyatakan oleh Pratiwi, Vinni Dini dan Wuryandani (2020) sebagaimana hasil penelitiannya bahwa model PBL dapat meningkatkan motivasi belajar siswa serta mengurangi kebosanan dalam menerima pelajaran Kewarganegaraan. Pemecahan masalah melalui kegiatan eksperimen dan eksplorasi lingkungan memberi kesempatan pada anak untuk berinteraksi langsung dengan dengan obyek pembelajaran dapat menambah wawwasan dan pengetahuan anak menjadi lebih bermakna (Rachmawati \& Kurniati, 2011), serta mampu meningkatkan keterampilan proses sains. Keterampilan proses merupakan kemampuan mengamati, membandingkan, mengelompokkan dan mengukur, serta mampu mengkomunikasikan hasil eksperimen (Marliza \& Eliza, 2019). Jadi anak mempelajari sains bukan dengan hapalan berbagai konsep yang abstrak.

\section{SIMPULAN}

Model pembelajaran Problem Based Learning dapat diterapkan untuk melatih kemampuan anak berpikir dan memecahkan masalah dengan mengajukan pertanyaan untuk diselesaikan. Model PBL mampu memotivasi anak lebih antuasias dalam mempelajari sains dengan melibatkan langsung dengan obyek pembelajaran dan praktik eksperimen yang menantang dapat menolong anak menemukan jawaban atas masalah yang diajukan. Kemandirian dan proses berpikir kritis serta kreativitas anak terasah melalui kemampuan anak mengikuti tahapan eksperimen. Konsep sains dipelajari anak melalui kegiatan yang menantang, menyenangkan dan bermakna. Anak dapat membangun sendiri pengetahuaannya tentang sains dan menghubungkannya dengan fenomena dan masalah yang terjadi di lingkungan dan kehidupan sehari-hari.

\section{UCAPAN TERIMA KASIH}

Ucapan terima kasih penulis haturkan kepada pihak-pihak yang telah memberikan masukan dalam pelaksanaan penelitian ini, yakni ; (1) Universitas Dhyana Pura yang telah memberikan kesempatan dan mendanai pelaksanaan penelitian ini. (2) Dr. I Gusti Bagus Rai Utama, SE. M.MA., MA. selaku Rektor Universitas Dhyana Pura, yang telah memberikan motivasi dan rekomendasi guna kelancaran pelaksanaan penelitian. (3) Putu Chris Susanto, B.A., MBA., M.Ed selaku Ketua Lembaga Penelitian dan Pengabdian Masyarakat Universitas Dhyana Pura, yang telah banyak memberikan arahan dalam pelaksanaan penelitian ini. Dan (5) Ni Kadek Suartini, S.E., M.Pd., selaku Kepala Sekolah PAUD Pelita Kasih Dalung yang telah memberikan ijin dalam pelaksanan penelitian ini.

\section{DAFTAR PUSTAKA}

Almulla, M. A. (2020). The Effectiveness of the Project-Based Learning (PBL) Approach as a Way to Engage Students in Learning. SAGE Open, 10(3). https:// doi.org/10.1177/2158244020938702 
Pengaruh Model Pembelajaran Problem Based Learning Berbasis Eksperimen Sederhana dalam Pengenalan Sains DOI: $10.31004 /$ obsesi.v6i3.1233

Crawford, B. A., \& Capps, D. K. (2018). Teacher Cognition of Engaging Children in Scientific Practices (pp. 9-32). Springer. https:// doi.org/10.1007/978-3-319-66659-4_2

Diastuti, I. M., \& Sulton, A. (2021). The Effectiveness of Problem Based Learning (PBL) Method Through Marquee Model to Cultivate Literacy. Tapis: Jurnal Penelitian Ilmiah, 4(2), 220. https:// doi.org/10.32332/tapis.v4i2.2573

Fidiyani, I. M., Nugraha, A., \& Mariyana, R. (2019). Peningkatan Kemampuan Kognitif Anak Melalui Penerapan Metode Eksperimen Dalam Pembelajaran Sains Pada Anak. Edukid, 14(1). https://doi.org/10.17509/edukid.v14i1.17089

Husin, S. H., \& Yaswinda, Y. (2021). Analisis Pembelajaran Sains Anak Usia Dini di Masa PANDEMI Covid-19. Jurnal Basicedu, 5(2), 581-595. https://doi.org/10.31004/basicedu.v5i2.780

Juniarti, Y. (2017). Penerapan Metode Eksperimen Dalam Meningkatkan Aktivitas dan Hasil Belajar Sains Anak. Pelita PAUD, 1(2), 73-84. http://jurnal.upmk.ac.id/index.php/pelitapaud/article/view/202/144

Permendikbud No 146, 2014. Kurikulum 13 Pendidikan Anak Usia Dini, (2014).

Marliza, R., \& Eliza, D. (2019). Peningkatan Keterampilan Proses Sains Melalui Kegiatan Belajar Tanaman Di Taman Kanak-Kanak Aba Air Bangis. JRTI (Jurnal Riset Tindakan Indonesia), 4(1), 59-63. https:// doi.org/10.29210/3003279000

Morrison, G. S. (2012). Dasar-Dasar Pendidikan Anak Usia Dini (PAUD). PT. Indeks.

Muharromi, D. S., \& Sa'ud, U. S. (2015). Pengaruh Penerapan Problem Based Learning Dalam Meningkatkan Kreativitas Dan Kemampuan Berbicara Pada Anak Usia Dini. Edutech, 15(1). https:// doi.org/10.22216/JCC.2016.v2i3.1277

O'Grady, Glen, Yew, Elaine H.J., P.L, Karen. Schmidt, G. H. G. E. (2012). One-Day, OneProblem An Approach to Problem-based Learning. Singapore Heidelberg New York Dordrecht London : Springer.

Pratiwi, V. D., \& Wuryandani, W. (2020). Effect of Problem Based Learning (PBL) Models on Motivation and Learning Outcomes in Learning Civic Education. JPI (Jurnal Pendidikan Indonesia), 9(3), 401. https://doi.org/10.23887/jpi-undiksha.v9i3.21565

Rachmawati, Y., \& Kurniati, E. (2011). Strategi Pengembangan Kreativitas pada Anak Usia Taman Kanak-Kanak. In Strategi Pengembangan Kreativitas Pada Anak TK. Kencana Prenada Media Group.

Seefeldt, C., \& Wasik, B. A. (2008). Pendidikan Anak Usia Dini: untuk Anak Usia 3, 4, dan 5 Tahun Masuk Sekolah. PT. Indeks.

Siagian, M. V. S. S., \& Sinaga, B. (2019). Development of Learning Materials Oriented on Problem-Based Learning Model to Improve Students' Mathematical Problem Solving Ability and Metacognition Ability. International Electronic Journal Of Mathematics Education, 14(2), 331-340. https:/ / doi.org/10.29333/iejme/5717

Sit, M. (2017). Psikologi Perkembangan Anak Usia Dini. Kencana.

Sugiyono. (2017). Metode Penelitian Pendidikan: Pendekatan Kuantitatif, Kualitatif, R\&D. Cetakan Ke-25. Bandung: CV Alfabeta.

Tan, O.-S. (2003). Problem-Based Learning Innovation: Using problems to power learning in the 21st century. In Gale Cengage Learning. Gale Cengage Learning.

Ulfa, M. (2020). Problem Based Learning (PBL) Model dalam Melatih Sikap Mandiri Anak Luar Biasa. ThufuLA: Jurnal Inovasi Pendidikan Guru Raudhatul Athfal, 8(2), 193. https:// doi.org/10.21043/thufula.v8i2.6702

Widiyarti, Wiwi, R. \&, \& Soetisna, U. (2021). Implementasi Pembelajaran Problem Based Learning(PBL) Untuk Meningkatkan Keterampilan Berpikir Kreatif dan Kemandirian Siswa. Jurnal Wahana Pendidikan, 8(1).

Wulandari, A., \& Suparno, S. (2020). Pengaruh Model Problem Based Learning terhadap Kemampuan Karakter Kerjasama Anak Usia Dini. Jurnal Obsesi : Jurnal Pendidikan Anak Usia Dini, 4(2), 862. https:// doi.org/10.31004/obsesi.v4i2.448 